\title{
Spatial unevenness of innovative and technological development of the territories of the Russian Federation
}

\author{
Olga Smirnova ${ }^{1,2^{*}}$, and Lyudmila Chesnyukova ${ }^{3}$ \\ ${ }^{1}$ Institute of Economics of the Ural Branch of the Russian Academy of Sciences, \\ Moskovskaya St. 29, 620014 Ekaterinburg, Russian Federation \\ ${ }^{2}$ Ural Federal University, Mira St. 19, 620002 Ekaterinburg, Russian Federation \\ ${ }^{3}$ Ural State University of Economics, 8 Marta/Narodnoi Voli str. 62/45, Ekaterinburg, Russian \\ Federation
}

\begin{abstract}
The study covers the topical aspects of the innovative and technological development of the Russian Federation from the standpoint of territorial unevenness. A quantitative and qualitative analysis of the factors of innovative and technological development of the federal districts of Russia has been carried out, the specificity of regional development has been investigated. The spatial analysis of the territories made it possible to conclude that there is a significant territorial concentration and differentiation in terms of innovative activity indicators. The paper shows a significant territorial disparity in the distribution of developed advanced production technologies. The structure of R\&D organizations has been displayed, it has been noted that the bulk of the organizations is concentrated in the Central Federal District of the Russian Federation. A spatial analysis of the territories of the Russian Federation from the standpoint of the innovative and technological potential made it possible to distinguish territories by the type of innovative development: 1) territories with a high level and an upward trend of innovative and technological development; 2) territories with a high level and a downward trend of innovative and technological development; 3 ) territories with a low level and an upward trend of innovative and technological development; 4) territories with a low level and a downward trend of innovative and technological development.
\end{abstract}

Keywords: spatial unevenness, innovation, technology, industry.

\section{Introduction}

The transition of the Russian economy from the export of mineral wealth to the innovative and technological development of territories is a very urgent process. A whole range of factors has a significant impact on the economic development of the federal districts of Russia. However, in modern conditions, investments and innovations are becoming more

\footnotetext{
* Corresponding author: smirnova.op@uiec.ru
} 
and more important. The general concept of innovative and technological development is understood as a set of various types of resources (advanced production technologies, R\&D costs, intellectual resources) necessary for the implementation of the innovative activity of a territory, namely, the creation of fundamentally new products or technologies, or modification of approved innovations [1]. In addition, at the present time, the introduction of advanced production technologies into the activities of industrial manufacturing within the framework of the dominant paradigms of socio-economic development gives rise to brand new advanced solutions aimed at industries, the ultimate goal of which will be the creation of new forms and models of business based on the principles of Industry 4.0.

\section{Literature Review}

Recently, the studies have been significantly expanding, the content of which links technological innovation with the regional innovative and technological development of the territories of the Russian Federation. In addition, one can state the importance of this issue in various reports and studies of both domestic and foreign scholars. There is a growing perception that research and development (R\&D) can stimulate growth in shrinking industrial regions and act as a starter for less economically prosperous regions.

Within the framework of the study, the key issues are the relationship between territorial development, innovation and technology: first, how to quantify regional innovation and technological potential; second, what are the determinants of innovation and what role localization plays; third, what are the tools for strengthening the technological potential of territories in order to increase regional competitiveness and economic growth.

The studies of domestic and foreign scholars are devoted to the problems of spatial unevenness of the innovative and technological development of the territories of the Russian Federation: Cohen and Levinthal [2], Fischer, Fröhlich and Gassler [3], Gadzhiev et al. [4], Morgan [5], Schmidt [6], Gamidullaeva [7], Zharov [8], Lavrikova, Akberdina and Suvorova [9], Skvortsova, Lebedeva and Sotnikova [10], Sukhovey and Golova [11].

\section{Materials and methods}

Note that there is currently no universal methodology for assessing the impact of innovative and technological development on the sustainability of territories. Let us single out the types of territories according to the indicator of innovative and technological development: 1) territories with a high level and an upward trend of innovative and technological development; 2) territories with a high level and a downward trend of innovative and technological development; 3) territories with a low level and an upward trend of innovative and technological development; 4) territories with a low level and a downward trend of innovative and technological development.

This study used statistical reports published by Rosstat. With the help of regression analysis, the degree of interrelation between the GRP indicators and the level of innovative and technological development was identified by the following indicators: the number of organizations that performed research and development; the number of personnel engaged in research and development; internal expenditures for research and development; developed advanced production technologies; advanced production technologies in use [12, 13].

To study the impact of innovation on the level of development of the territory, constructing a linear regression equation and finding the coefficients of determination $\mathrm{R}^{2}$.

The paired linear regression equation is:

$$
\bar{y}=a x+b
$$


where $y$ is gross regional product by federal districts of the Russian Federation; $x$ is the factor influencing the a and b-regression coefficients (the level of innovative and technological development of the federal districts).

If $\mathrm{a}>0$, then with an increase in the coefficient $x$, the volume of the gross regional product increases, and if $\mathrm{a}<0$, then with an increase in the coefficient $x$, it decreases.

To check the adequacy of the equation, finding the coefficient of determination by the formula (2):

$$
R^{2}=1-\frac{\sum(y i-a x i-b)^{2}}{\sum(y i-\bar{y})^{2}}
$$

where $y_{i}$ is gross regional product in the $\mathrm{i}$-th year; $x_{i}$ is factorial estimate in the $\mathrm{i}$-th year; $y$ is the gross regional product by federal districts of the Russian Federation over several years.

The closer $\mathrm{R}^{2}$ is to 1 , the stronger the relationship between $\mathrm{x}$ and $\mathrm{y}$.

The estimated regression equation determines the analytical relationship of changes in the effective indicator by the influence of one or several factor indicators and shows that, in aggregate, the relative economic well-being of a territory is proportional to the level of innovative and technological development.

\section{Results and discussion}

Innovative activity and the introduction of technological innovations are strategically important indicators for the growth and development of business. In 2019, according to the analysis of innovation activity in 8 federal districts, it was found that the number of research institutions in Russia reached 4,051, most of which are concentrated in the Central Federal District. It should also be noted that the structure of the number of personnel in the federal districts engaged in research and development is not homogeneous. In the context of federal districts, the largest share of internal expenditures on research and development in federal districts belongs to the Central $(50.8 \%$ of the total expenditures on research and development in Russia), the Volga $-16.4 \%$ and the North-West $-14.6 \%$. The introduction of new advanced technologies in industrial manufacturing is one of the leading priorities, while innovations are one of the key factors in the development of industries.

There is a significant territorial disparity in the distribution of developed technologies. It is important to note some structural changes in the geography of technological development. If in 2010, compared to previous periods, the share of the Central Federal District increased and amounted to $41.8 \%$, then after 2010 there is a decrease in the share (down to 28.9\% in 2012), and in 2013, there is a gradual increase in the share of developed advanced production technologies up to $35 \%$. Similar changes are noted in the North-West Federal District (in 2005 its share was $16.2 \%$, in 2012 it increased to $24.2 \%$, and in 2018 it decreased to $11.8 \%$ ). The Volga Federal District and the Ural Federal District also demonstrate a decrease in their shares in the territorial structure in $2012-16.4 \%$ and $11.6 \%$, respectively. Then a positive trend is observed, therefore, despite the continuing priority in the development of advanced production technologies in the Central Federal District, over time, research and production centers are developing in other regions of Russia.

The dynamics of changes in the innovation activity of the federal districts of Russia is shown in Table 1. 
Table 1. Dynamics of changes in the level of innovative and technological development of federal districts in 2005-2019, share units.

\begin{tabular}{|l|c|c|c|c|c|c|c|}
\hline \multicolumn{1}{|c|}{ Federal district } & $\mathbf{2 0 0 5}$ & $\mathbf{2 0 1 0}$ & $\mathbf{2 0 1 5}$ & $\mathbf{2 0 1 6}$ & $\mathbf{2 0 1 7}$ & $\mathbf{2 0 1 8}$ & $\mathbf{2 0 1 9}$ \\
\hline Central & 0.403 & 0.436 & 0.411 & 0.403 & 0.405 & 0.394 & 0.391 \\
\hline North-West & 0.119 & 0.129 & 0.128 & 0.127 & 0.125 & 0.120 & 0.129 \\
\hline South & 0.038 & 0.038 & 0.046 & 0.046 & 0.047 & 0.049 & 0.053 \\
\hline North-Caucasian & 0.010 & 0.012 & 0.013 & 0.012 & 0.013 & 0.014 & 0.014 \\
\hline Volga & 0.204 & 0.174 & 0.180 & 0.183 & 0.177 & 0.184 & 0.176 \\
\hline Ural & 0.078 & 0.079 & 0.083 & 0.088 & 0.089 & 0.089 & 0.088 \\
\hline Siberian & 0.079 & 0.075 & 0.078 & 0.079 & 0.083 & 0.086 & 0.083 \\
\hline Far-East & 0.032 & 0.026 & 0.028 & 0.027 & 0.029 & 0.029 & 0.025 \\
\hline
\end{tabular}

As follows from Table 1, high innovation activity is observed in the Central, NorthWest and Volga Federal Districts. Outsiders are the South, North-Caucasian and Far-East Federal Districts.

When distributing federal districts by types of innovative activity, the following can be noted: territories with a low level of innovative and technological development are identified, these include the Ural, Siberian, North-Caucasian and South Federal Districts, as well as territories that experienced a decline in innovative and technological activity throughout the analyzed period (Far-East and Volga Federal Districts). Assessment of the impact of the level of innovative and technological development on the territorial economic development showed that the Central, North-West and Volga Federal Districts have high innovative activity; in addition to the costs of internal development and the introduction of new technologies, other factors related to the industry specificity of the territories also have an impact.

In this study, the authors will identify a trend component that describes the influence of the level of innovative and technological activity on the economic development of federal districts. For this purpose, paired linear regression equations have been constructed that describe the considered time series of the main growing trend. As this level, the authors identified the power mean value of the indicator "innovation and technological activity" in shares of the total number of surveyed organizations of the corresponding federal district, which is an exogenous (influencing) variable. The endogenous (dependent) variable (y) is the value of the gross regional product.

These calculations made it possible to distinguish the types of territories by the indicator of innovative and technological development. The federal districts with an upward trend in innovative and technological development include the South, North-Caucasian, Ural and Siberian Federal Districts. The federal districts with a downward trend in innovative and technological development include the Central, North-West, Volga and Far-East Federal Districts. A comparison of the level of innovative and technological development of federal districts and the trend of innovative activity made it possible to group the territories as follows in Table 2.

Table 2. Typification of federal districts by the level of innovation and technological development and the trend of innovative activity.

\begin{tabular}{|l|l|}
\hline \multicolumn{1}{|c|}{ Classification } & \multicolumn{1}{|c|}{ Federal districts } \\
\hline $\begin{array}{l}\text { territories with a high level and an upward trend of innovative and } \\
\text { technological development }\end{array}$ & None \\
\hline $\begin{array}{l}\text { territories with a high level and a downward trend of innovative } \\
\text { and technological development }\end{array}$ & Central, North-West, Volga \\
\hline $\begin{array}{l}\text { territories with a low level and an upward trend of innovative and } \\
\text { technological development }\end{array}$ & $\begin{array}{l}\text { South, North-Caucasian, Ural, } \\
\text { Siberian }\end{array}$ \\
\hline $\begin{array}{l}\text { territories with a low level and a downward trend of innovative and } \\
\text { technological development }\end{array}$ & Far-East \\
\hline
\end{tabular}


Attention should be paid to the absence of type 1 federal districts (with a high growth of innovation activity. Type 2 federal districts, which are characterized by a transition to a relatively successful group of innovative activities, include the Ural, Siberian, NorthCaucasian and South Federal Districts. Currently, in these districts, a specialized infrastructure is being strengthened, which ensures the interaction of government authorities with economic entities focused on innovations and the development of innovative potential.However, the territories that experienced a decline during the analyzed period were identified as the Far-East and Volga Federal Districts.

Taking into account the distribution of the innovative and technological activity of the federal districts in Russia and the identification of negative causes that give rise to imbalances, one should put a question about solutions seeking the formation of innovative potential, primarily in connection with technologically underdeveloped territories.

Table 3. Comparison of innovative activity models by federal districts.

\begin{tabular}{|l|l|c|}
\hline \multicolumn{1}{|c|}{ Federal district } & \multicolumn{1}{c|}{ Regression equation } & \multicolumn{1}{c|}{$\mathbf{R}^{\mathbf{2}}$} \\
\hline Central & $\mathrm{y}=-212.319 \mathrm{x}+10.6053$ & 0.1479 \\
\hline North-West & $\mathrm{y}=-49.981 \mathrm{x}+12.735$ & 0.0321 \\
\hline South & $\mathrm{y}=215.943 \mathrm{x}-5.211 .2$ & 0.7079 \\
\hline North-Caucasian & $\mathrm{y}=26.8826 \mathrm{x}-1.763 .8$ & 0.6692 \\
\hline Volga & $\mathrm{y}=-228.729 \mathrm{x}+50.860$ & 0.3856 \\
\hline Ural & $\mathrm{y}=612565 \mathrm{x}-42568$ & 0.8284 \\
\hline Siberian & $\mathrm{y}=276.413 \mathrm{x}-16.756$ & 0.2249 \\
\hline Far-East & $\mathrm{y}=-312.889 \mathrm{x}+12.318$ & 0.2288 \\
\hline
\end{tabular}

Analyzing the obtained equations, one can conclude that a close relationship between the GRP and the level of innovation and technological development is observed in the South, North-Caucasian and Ural Federal Districts (Table 3). Due to differences in the sectoral structure, there is a low dependence of the GRP on the level of innovation and technological development in the Central and North-West Federal Districts [14]. Thus, the typification of the federal districts of Russia made it possible to distinguish several groups by the level of innovative and technological development.

\section{Conclusion}

An analysis of the innovative and technological development of the territories of the Russian Federation leads to a number of conclusions. Despite the economic instability in Russia, the number of advanced production technologies developed in 2005-2019 has increased, which is a positive trend, although Russia is far from the world leaders by this indicator. Traditionally, the Central and North-West Federal Districts are considered technologically more advanced in the framework of Russia's innovative development until 2030. It is obvious that less developed territories should not be deprived of the opportunity to increase their innovation potential as innovation policy is mainly aimed at achieving national efficiency goals. Thus, it can be concluded that further analysis of the factors influencing the number of advanced production technologies and, in general, the innovative and technological development of territories is necessary. 


\section{References}

1. O.E. Kuzmina, Vestnik of the UrFU. Series: Economics and Management, 6, 28-35 (2014). Accessed on: June 27, 2021. [Online]. Available: https://www.elibrary.ru/item.asp?id=22736383

2. W.M. Cohen, D.A. Levinthal, Economic Journal, 99, 569-596 (1989)

3. M.M. Fischer, J. Fröhlich, H. Gassler, Regional Studies, 28(1), 1-12 (1994)

4. Y.A. Gadzhiev et al., Economic and Social Changes: Facts, Trends, Forecast, 48, 236254 (2016)

5. K. Morgan, Regional Studies, 31(5), 491-503 (1997)

6. C. Schmidt, International Advances in Economic Research, 2(1), 255-270 (1996)

7. L.A. Gamidullaeva, Science, Education, Society, 1(3), 10-17 (2015)

8. V.S. Zharov, Trends and prospects for innovative industrial development of the regions of the North and the Arctic. Trends in the development of the economy and industry in the context of digitalization, in A.V. Babkin (ed.), 374-397 (Saint Petersburg, 2017)

9. Yu.G. Lavrikova, V.V. Akberdina, A.V. Suvorova, Economics and Management, 26(7 (177)), 698-707 (2020)

10. N.A. Skvortsova, O.A. Lebedeva, E.A. Sotnikova, Fundamental Research, 2, 1265 $1268(2015)$

11. A.F. Sukhovey, I.M. Golova, Economy of Region, 16(4), 1302-1317 (2020)

12. Innovations, Federal State Statistics Service (Rosstat) (Moscow, 2021). Accessed on: June 5, 2021. [Online]. Available: https://rosstat.gov.ru/folder/14477

13. O.P. Smirnova, A.O. Ponomareva, Economic Analysis: Theory and Practice, 18(8(491)), 1523-1542 (2019)

14. N.M. Sergeeva, Russian Journal of Entrepreneurship, 20(3), 645-654 (2019) 